\title{
TÁRSADALMI-KULTURÁLIS KÉRDÉSEK ÉS A TRADÍCIÓK SZEREPE A SERTÉSHÚSFOGYASZTÁSBAN
}

\author{
- hी - \\ THE ROLE OF SOCIO-CULTURAL ISSUES AND TRADITIONS REGARDING \\ PORK CONSUMPTION \\ $-10$ \\ VIDA, Viktória \\ SzÜCS, Istuán \\ ia.
}

Debreceni Egyetem, Gazdaságtudományi Kar, Gazdálkodástudományi Intézet, Üzemtani és Vállalati Tervezés Tanszék (University of Debrecen, Faculty of Economics and Business, Institute of Applied Economics Sciences, Department of Farm Business Management and Corporate Planning)

H-4032 Debrecen, Böszörményi út 138.

e-mail: vida.viktoria@econ.unideb.hu

\begin{abstract}
gi
Examining the pork consumption, the differences in the cultural and religious habits should be mentioned, because pork meat is the most affected in religious restrictions regulations. In this article we present the cultural and religious impact on pork consumption. The religious affiliation/identity is basically determined by the food and consumer habits, too. Due to the differences in dietary habits and religious culture, we think that the consumption of pork can be highly varied from country to country as well. Therefore, examining the data of global pork consumption the conclusion is justified that the pork consumption per capita/year in the world does not give a full and true picture. We try to calculate the corrected pork consumption per capita/ year data in the world considering the religious regulations and cultural habits. This corrected data shows a more complete picture about pork consumption in the world.
\end{abstract}

KulCSSZAVAK: éves egy főre jutó sertéshúsfogyasztás, vallás, kultúra, hagyományok

JEL-KóDOK (JEL CODES): A13, P46

\section{BEVEZETÉS - INTRODUCTION}

A sertéshúsfogyasztás témakörét vizsgálva mindenképpen említést kell tenni a kulturális szokásokban lévő különbözőségekről, hiszen a húsfélék közül a sertéshús az, amelyik a leginkább érintett az eltérő kulturális környezet, a vallási korlátozások és a kapcsolódó szabályozások által, ezért a következőkben a kultúra és a vallás sertéshúsfogyasztásra gyakorolt hatását kívánjuk bemutatni.

A kultúra az élelmiszer-fogyasztói magatartást befolyásoló tényezők közül a legösszetettebb, legbonyolultabb, legelvontabb fogalom
KEYWORDS: per capita pork consumption, religion, traditions és kapcsolatrendszer. A kultúra egyaránt integrálja az egyéni, a társadalmi (csoport), illetve a pszichológiai tényezőket és összetevőket. A kultúra kettős felosztása a legelterjedtebb: egyrészt a fizikai, az anyagi/látható tényezők, mint például az épületek, az infrastruktúra, az öltözködés, az élelmiszerek és fogyasztásukhoz kapcsolódó eszközök, másrészt a nem anyagi/ láthatatlan tényezők, mint például az értékek, a szokások, a normák, a szabályok és az eszmék. $\mathrm{Az}$ élelmiszereket minden kultúrában széles körűen szimbólumként is használják, amelyek közül a leggyakoribbak a következők: (1) a vallási jelentés; (2) a kulturális tabuk és kvázi 
tabuk a más kultúráktól való elhatárolódás jelképei; (3) a rituális jelleg (pl. az esküvői, a születésnapi torta, a szilveszteri pezsgő, az újévi malac, a húsvéti sonka); (4) a csoporthoz való tartozás kifejezése (pl. etnikum, család, stb.) (LEHOTA, 2001).

A kultúrák egyik alappillére az adott kultúrában uralkodó vallási hovatartozás. Az európai kultúrában az uralkodó vallás a kereszténység, mely nem ír elő szigorú tilalmakat egyes ételek, illetve élelmiszerféleségek fogyasztására vonatkozóan, viszont vannak olyan ettől eltérő kultúrák, amelyek jelentős korlátozásokat határoznak meg bizonyos ételek, ételcsoportok fogyasztását illetően. A sertéshús, a sertéshúsból készült ételek sok esetben ezek közé tartoznak, mivel a sertéshús az egyik, a kultúra és a vallás által leginkább érintett élelmiszerféleség, illetve alapanyag, amelynek fogyasztására különböző tilalmak érvényesek.

A sertéshús esetében megállapíthatjuk, hogy a sertéshúsnak szembesülnie kell vallási és kulturális korlátozásokkal, nem úgy, mint a baromfihúsnak (THE POULTRY SITE, 2009).

E helyütt említést kell tenni a fejlett világban egyre inkább terjedő vegetáriánus táplálkozásról. A vegetarianizmus a nevéből eredően az a táplálkozási gyakorlat, melynek követője bármilyen állat megölésével elkészített táplálék elfogyasztását elveti. Több formában létezik, aszerint, hogy a húson kívül mely ételek fogyasztása tilos. Vannak, akik elutasítják a tejet és a tejtermékeket, vagy a tojást. A szigorúbb vegán táplálkozás semmilyen állati eredetű ételt nem enged meg, tehát ezek sem fogyaszthatók, és még a mézet is tiltják. Az ún. nyers-evők többnyire foott vagy sült ételeket sem esznek. A vegetarianizmus világnézete a modern társadalmakban a reform- vagy natúrtáplálkozási irányzatok egyike, így követői rendszerint nagy hangsúlyt fektetnek az egészség tudatos megőrzésére. Emellett a hústermelés ökológiai költségessége, illetve a nagyipari előállításhoz társuló jelentős környezetterhelés és környezetszennyezés következtében kapcsolatban áll a környezetvédelemmel; az állatok életminőségének, leölésének és tárgyként való kezelésének etikai aggályai miatt pedig szorosan összefonódik az állatvédelemmel és az állatjogi mozgalommal is. Sok vegetáriánus számára így ez nemcsak táplál- kozási gyakorlat, hanem egy kiterjedt eszmerendszer, világnézet, illetve fogyasztói filozófia, melyet az a fö törekvés jellemez, hogy az ember a lehetőségeihez mérten minél kevesebb állatnak okozzon szenvedést, különös tekintettel a tudatos, fejlett idegrendszerrel rendelkező állatokra. Mások a húsevést egyéb okból kifolyólag utasítják el, például azért, mert nem szeretik, undorodnak a nyers hústól, vagy pedig azért, mert a diétájuk nem engedi meg. A vegetarianizmus először Indiában és tőle függetlenül az ókori görög világban jelent meg. Mindkét kultúrában kezdettől fogva vallási-filozófiai törekvések része volt.

Jelen tanulmányunknak a legfontosabb célkitűzése, hogy vallási hovatartozást is figyelembe véve, elkülönítve határozza meg az egy före jutó éves globális sertéshúsfogyasztás alakulását. Illetve kiemelten vizsgáljuk Kína kulturális szokásait és fogyasztását a sertéshússal kapcsolatban, mivel, mint a világon a legnagyobb sertéshús előállító és fogyasztó ország, egymaga jelentős hatással tud lenni a világ sertéshús termelésére, kereskedelmére és fogyasztására is.

\section{ANYAg ÉS MÓDSZER - MATERIAl AND METHOD}

A világ egy főre jutó sertéshús-fogyasztási mutatójának korrekciójához kalkulációs elemzést végeztünk. A rendelkezésre álló adatok viszonylag nehezen elérhetőek, és több forrást is meg kellett vizsgálni ahhoz, hogy a megfelelő, releváns adatokat találjuk a kalkulációhoz. A szükséges adatokat a sertéshús fogyasztására vonatkozóan a FAOSTAT adatbázisban értük el, ahol a legfrissebb adatok 2013-ra vonatkoznak. A világ népességének adatait, a népesség vallási hovatartozás szerinti megoszlását pedig a CIA weboldalán elérhető THE WORLD FACTBOOK (2016) adatai alapján kalkuláltuk.

A számítási módszertan menete úgy épült fel, hogy első lépésben beazonosítottuk a FAOSTAT adatbázisból a világon felhasznált/ elfogyasztott összes sertéshús mennyiségét kilogrammban, majd a világ népességét fóben. Ennek a két adatnak a hányadosa adja a világ egy főre jutó sertéshús-fogyasztását kilogrammban kifejezve az adott évre vonatkozóan. 
Ezt követően a világ népességét felosztottuk - a THE WORLD FACTBOOK (2016) adatai alapján - arányszámok segítségével a különböző vallások szerint. A világ népességének vallások szerinti felosztásából összeadtuk azokhoz a vallási felekezethez tartozókat, akik a vallási hovatartozásuk, a kulturális különbözőségek, a korlátozások miatt nem fogyasztanak sertéshúst (muszlim, hindu, buddhista, izraelita vallásúak), majd a kapott eredményt kivontuk a világ összes népességéből főben meghatározva. Így meghatároztuk a világ népességének (fö) azon részét, akik a vallási hovatartozásuk miatt nem esnek semmilyen korlátozás alá a sertéshúsfogyasztást illetően, így őket tekinthetjük a „tényleges sertéshúsfogyasztóknak”. Majd a világ összes sertéshús felhasználását (kilogramm) elosztottuk a „tényleges sertéshúsfogyasztókkal” (fö), így kaptuk meg a világ korrigált sertéshús-fogyasztási mutatóját $\mathrm{kg}$ /fö/év mértékegységben.

\section{EREDMÉNYEK - RESUltS}

A saját fogyasztói szokásaink, a saját kultúránk számunkra teljesen természetes, míg egy tőlünk idegen kultúra, annak szokás- és normarendszere, számunkra sokszor rendkívül furcsának hat. Ahogyan azt már korábban is említettük, az egyik legfontosabb kulturális különbség a világ népei között a vallásban, a vallási hovatartozásban van, mert meghatározza az emberek mindennapjait, ezzel együtt a fogyasztási szokásait is. A fogyasztási szokások között az élelmiszerfogyasztás, azon belül is a húsfogyasztás a leginkább korlátozás alá eső élelmiszer a különböző vallási kultúrákban.

\subsection{A kultúra és a vallás sertéshúsfo- gyasztásra gyakorolt hatása - \\ The Impact of Culture and Religion on the Pork Meat Consumption}

Közelebbről megvizsgálva a vallás témakörét, az öt világvallásból indulhatunk ki. Ezek a következőek: bráhmanizmus (közismertebb nevén hinduizmus), buddhizmus, kínai univerzizmus, kereszténység és az iszlám. Ezt egészítettük még ki az izraelita vallással, mert közismert, hogy a zsidó és az iszlám vallásúak esetében tilos a sertéshús vagy bármely részének fogyasztása, a hinduizmusban a marhahús jelent tilalmat.

A hinduizmus egyik alapvető írása, Manu törvénykönyve egyértelmúen felhívja a figyelmet a húsevés erkölcsi vonatkozásaira: „A következő emberek minősülnek az állat gyilkosának: aki megengedi, aki megöli, aki feldarabolja, aki eladja, aki megveszi, aki elkészíti, aki felszolgálja, és aki megeszi." (Manuszmriti 5.51). A hinduizmus legfontosabb szent iratában, a Bhagavad-gítában is a húsmentes életmód követését ajánlja Isten (Krisna): „Ha valaki szeretettel és odaadással áldoz Nekem egy levelet, egy virágot, egy gyümölcsöt vagy egy kevés vizet, Én elfogadom azt." (KRISNA, 2011). Indiában a vallásos hinduk $43 \%$-a vegetáriánus; a nem vallásosok esetében ez az arány 28\% (YADAV és KUMAR, 2006).

A buddhizmus esetében már maga a vallásalapító, Buddha is vegetáriánus volt, és a vallás alapvető parancsolataiban (a nemes nyolcrétű ösvényben) is az erőszak-nélküliség követésére buzdít. Más buddhista iratok is nyíltan szembeszállnak az állatok elpusztításával. „A Bódhiszattva, aki tart attól, hogy az élőlényeknek félelmet okozzon, aki arra neveli magát, hogy együttérzést tanúsítson, visszatartja magát a hús evésétől” (Lankávatára). Egy másik helyen található az alábbi intelem: „A húsevés elpusztítja a nagy együttérzés magját." (Maháparinirvána). Az ókori India nevezetes buddhista uralkodója, Asoka pedig külön rendeletben szabályozta az állatok védelmét (KRISNA, 2011). A buddhizmus tehát nem parancsolja a követőit a húsok mellőzésére, hanem utat mutat a tárgyaktól független emberi boldogsághoz, amelynek a húsfogyasztás önkéntes mellőzése csupán egy mellékes, ámde szükségszerű folyománya (MORVAY, 2016).

A vallások közül a dzsainizmusban az erőszak-nélküliség (ahimsa) és a vegetáriánus életmód egyik legradikálisabb megvalósításával találkozhatunk. A hinduizmus és az iszlám kultúrájából születő, Indiában őshonos szikh vallás tanításai nem utalnak arra, hogy a vegetarianizmus kívánatos lenne, hanem az egyénre bízzák a döntést (MORVAY, 2016).

A kínai univerzalizmus nem tartalmaz korlátozást a sertéshús fogyasztására, ezt bizonyítják Kína sertéshús-fogyasztási mutatói, illetve 
nem szabad figyelmen kívül hagynunk Kína politikai berendezkedését sem, amely nem támogatja a vallást.

A kereszténység nem ismer vallási tabukat, a valláson belül jellemzően nem találunk sertéshúsra vonatkozó tilalmat, de a protestáns keresztény egyházon belül a 19. században létrejött közösségek közül néhány vegetáriánus elveket vall. Ezek szúk csoportok, ide tartoznak a metodista egyház hívei, a hetednapi adventisták, valamint a mormonok.

Az iszlám vallásban tiltott azoknak az állatoknak a fogyasztása, amelyek korábban állati eredetû anyagot tartalmazó tápon éltek, és tilos a vért tartalmazó ételek fogyasztása, mint a párizsi, vagy más felvágottak, valamint a véresen levágott állatok fogyasztása. Tilos sertészsírral sütni, és minden olyan ételt elfogyasztani, amiben sertéstől származó adalék, például szalonna található. A sertéshús tilalma négy helyen nyert említést a Korán különböző részeiben:

- Korán (2/173): „Allah megtiltotta nektek a döglött állat húsát, a vért, a disznóhúst, és aminek a levágásakor nem Allahhoz, hanem máshoz fohászkodtak. Ám, aki kényszerü helyzetben eszik ilyesmit, anélkül, hogy a tilalmast áhítozná, vagy át akarná hágni az előírást, az nem követ el vétséget."

- Korán (5/3): „Tilalmas nektek a döglött állat húsa, a vér, a disznóhús, és aminek a levágásakor máshoz fohászkodnak, mint Allah; a megfojtott, az agyoncsapott, a zuhanás miatt halálra zúzódott, a más állattól felöklelt, a vadállatoktól szétmarcangolt állatok húsa."

- Korán (6/145): „Abban, ami kinyilatkoztatott nékem, nem lelem azt, hogy bármi is tilalmas lenne a táplálkozó étkéül, kivéve az elhullott állat húsa, a levágáskor elfolyt vér és a disznó húsa - ez tisztátalanság - és a förtelmes hús, aminek a levágásakor máshoz hangzik el a fohász, nem Allahhoz. Ám aki kényszerű helyzetben eszik ilyesmit, anélkül, hogy a tilalmat áhítozná, vagy át akarná hágni az előírást, azt nem terheli vétség."

- Korán (16/115): „Megtiltotta nektek a döglött állat húsát, a vért, a disznóhúst és azt, amit másért vágtak le, mint Allahért." (EIHIT, 2011).
Az izraelita vallás, a zsidóság esetében a mózesi törvények határozzák meg, hogy mi minősül ehetőnek, azaz kósernek. A húsfélék közül kósernek minősül a marha, a juh, a kecske, a szarvas, az őz, a bivaly, vagyis minden hasadt patájú és egyben kérődző állat. Fogyaszthatók a szárnyasok közül a tyúk, a pulyka, a liba, a kacsa és a galambfélék. Tisztátalanok az egész talpukon járók a ló, a szamár, az öszvér és az olyan állatok, amelyek kérődznek, de nem hasított körmüek. A sertéshúsra és az abból készült ételekre érvényes a legnagyobb tilalom, még megérinteni sem szabad. A sertés iránti undor a zsidóságnál egyrészt történelmi okokra vezethető vissza, mert az elnyomók többször is rá akarták kényszeríteni a sertéshús fogyasztására a zsidókat, és ez szimbolikusan a hit megtagadását jelentette volna számukra (TUSOR, 2011).

A fent leírtak alapján megállapítható, hogy a vallási hovatartozás alapvetően meghatározza a táplálkozási, fogyasztási szokásainkat is. A kulturális és vallási szokásokban lévő táplálkozási különbségek miatt úgy gondoljuk, hogy a sertéshús kedveltsége igen változónak mondható akár országonként is. Éppen ezért a világ sertéshúsfogyasztásának adatait vizsgálva indokoltnak tartjuk azt a megállapítást, hogy a világ egy főre jutó sertéshús fogyasztási adatai a vallási korlátozások miatt nem mutatnak teljes, valós képet, hiszen az előbb említésre került, hogy az iszlám és az izraelita vallásúaknál tiltott a sertéshús fogyasztása, tehát az ő fogyasztásuk gyakorlatilag zéró. A feltételezésünk abból indult ki, hogy ha a világ átlagos éves sertéshús fogyasztásának mennyiségét (kg/fő/év) szeretnénk a valósághoz hủen szemléltetni, akkor a vallási hovatartozásból adódó „torzításokat” ki kell venni, ezt az értéket korrigálni kell. A valós kép meghatározásához egy újszerű kalkulációt kell elvégezni, melynek lépéseit a következőkben ismertetjük (1. táblázat).

A számítás során abból indultunk ki, hogy a világ átlagos egy fơre jutó sertéshús fogyasztási mennyisége 15,52 kg/fó/év volt 2009-ben a FAOSTAT adatbázisa alapján. Ezt az értéket úgy kapjuk, hogy a világ összes sertéshús felhasználását $(\mathrm{kg})$ elosztjuk a világ lakosainak számával (fö). Ezt az értéket kiszámoltuk 2011, 2013, 2015-re is, ez látható az 1. táblázat oszlopaiban. Majd a népesség adataiból kivettük 
azokat az embereket, akik a vallási hovatartozás miatt nem fogyasztanak sertéshúst, így kaptuk meg a „tényleges sertéshúsfogyasztókat”. Végezetül a világ sertéshús-fogyasztási adatait elosztottuk a „tényleges sertéshúsfogyasztókkal” megkapva így a korrigált egy före jutó mutatót.

\section{TÁBLÁZAT}

TABLE 1

A világ egy fóre jutó korrigált sertéshús fogyasztási mutató 2009, 2011, 2013,2015 (The Corrected Per Capita Pork Consumption 2009, 2011, 2013, 2015)

\begin{tabular}{|c|c|c|c|c|}
\hline & 2009 & 2011 & 2013 & 2015 \\
\hline $\begin{array}{l}\text { Összes húsfogyasztás a világon, tonna } \\
\text { (Total meat consumption in the world, tonnes) }\end{array}$ & 281482000 & 290078000 & 307057000 & 317582000 \\
\hline $\begin{array}{l}\text { Sertéshúsfogyasztás a világon, tonna } \\
\text { (Total pork consumption in the world, tonnes) }\end{array}$ & 105995000 & 106587000 & 113947000 & 119548000 \\
\hline $\begin{array}{l}\text { Világ népessége, } 1000 \text { fó } \\
\text { (Population in the world, } 1000 \text { capita) }\end{array}$ & 6828000 & 6847859 & 7181715 & 7349472 \\
\hline $\begin{array}{l}\text { Egy főre jutó sertéshúsfogyasztás, } \mathrm{kg} / \text { fö/év } \\
\text { (Pork consumption, } \mathrm{kg} / \text { capita/year) }\end{array}$ & 15,52 & 15,57 & 15,87 & 16,27 \\
\hline $\begin{array}{l}\text { Tényleges sertéshús fogyasztók, } 1000 \text { fö } \\
\text { (Corrected pork consumers, } 1000 \text { capita) }\end{array}$ & 3721260 & 3732083 & 3914035 & 4005462 \\
\hline $\begin{array}{l}\text { Korrigált egy före jutó sertéshús fogyasztási mutató, } \\
\mathrm{kg} / \text { fö/év (Corrected pork consumption, } \mathrm{kg} / \text { capita/year) }\end{array}$ & 28,48 & 28,56 & 29,11 & 29,85 \\
\hline
\end{tabular}

Forrás (Source): Az EUROSTAT, FAOSTAT, CIA adatai alapján saját kalkuláció, 2016 (Own calculation according to EUROSTAT'S, FAOSTAT'S and CIA's data, 2016)

A kapott adatok alapján megállapítást nyert, hogy a korrigált, azaz a vallás által nem korlátozott népesség egy főre jutó sertéshús fogyasztási mutatója majdnem a duplája az általánosan használt statisztikai adatnak. Mindenképpen meg kell említenünk, hogy ez a korrigált adat nem 100\%-os pontosságú, de mégis egy sokkal közelebbi, pontosabb képet mutat a világ átlagos egy före jutó sertéshús fogyasztásának adatairól. A közel $30 \mathrm{~kg} /$ fő fogyasztási mennyiség magyarázata abban rejlik, hogy a világ népességének 45,5\%-a valamilyen vallási korlátozás miatt nem fogyaszt sertéshúst. Ezt szemlélteti a 2. táblázat, mely a korrekciós számításokhoz tartozó segédleteket tartalmazza.

A vallási különbségek szemléltetéséhez szükségünk volt egy olyan táblázatra, amely a világ népességét vallásonként osztja fel. A kalkulációs számítás során a világ népességének legfrissebb hivatalos adatát vettük alapul, miszerint 7181715104 fó él jelenleg a világon. A rendelkezésre álló adatok alapján a főbb vallások arányszámát lakosokra vetítve kiszámoltuk, így megkaptuk, hogy 3267680372 fő az a világon, aki nem fogyaszt valamilyen vallási korlátozás miatt sertéshúst, ez a világ népességének 45,5\%-a (2. táblázat).
A korrekciós eljárás során azért ezzel az arányszámmal kalkuláltunk minden egyes évben, mert ez egy viszonylagos állandónak tekinthető abból a szempontból, hogy a korábban már említett kulturális szokásokból, hagyományokból adódóan kevesen térnek át másik hitre, vagy hagyják el a vallást. Valószínúleg ez is egy oka lehet annak, hogy évról évre nem készítik el az erre vonatkozó statisztikát, illetve ma még mindig tabu témának számít a vallási hovatartozás, így nagyon nehézkes beszerezni ezeket az adatokat. A 2. táblázatban nem tüntettük fel az összes vallási csoportot, csak azokat, amelyek a korrekció szempontjából számunkra relevánsak voltak.

Végezetül a kultúra, mint a fogyasztást befolyásoló tényező esetében említenünk kell még a nemzeti és rituális jelleget is, azaz a hagyományokat, szokásokat, ünnepeket, amelyek a sertéshús fogyasztásával kapcsolatosak. Magyarországon az ételek elkészítésének módjai döntően a főzés, illetve a sütés. A hagyományok alapján régebben magasabb presztízs értékű volt a sütés, amely elsősorban a húsok elkészítésére jellemző. A magyar ételfogyasztásban károsnak ítélt magas zsírfelhasználás ehhez a hagyományhoz kapcsolódik. Az étkezések szá- 
ma, illetve idópontja szintén kihat az életmód egészére (a munka ütemére, a társadalmi kapcsolatokra). Magyarországon a hármas étrend az újkorban terjedt el, amely reggeliből, ebédból és vacsorából áll. A napi ciklusokon túl fontos a heti, illetve az éven belüli ciklusok szerepe is. A heti ciklusokat is hosszú ideig alapvetően a vallási előírások (böjt) határozták meg. Fontos étkezési ciklusokat takart a hétköznapok és az ünnepek változása, illetve az absztinens időszakok és az ünnepek váltakozása (családi események: születés, keresztelés, lakodalom, temetés, illetve az egyházi ünnepek: nagyböjt/ húsvét, advent/karácsony, közösségi ünnepek: pl. a búcsú, a társadalmi ünnepek, a szilveszter/újév). Az ünnepekhez kapcsolódnak legszélesebb körüen a presztízs és bőség szimbólumai (pl. főtt sonka, kalács, stb.), a termékenységi szimbólumok (pl. főtt tojás, újévi malac, stb.) (LEHOTA, 2001).

\section{TÁBLÁZAT}

A kalkulációban szereplő (sertéshús fogyasztást tiltó) világvallások

TABLE 2 (The Number of the Followers of World Religions (Who Prohibit the Consumption of Pork) in Our Calculation)

\begin{tabular}{|c|c|c|}
\hline $\begin{array}{c}\text { Vallás } \\
\text { (Religion) }\end{array}$ & $\begin{array}{l}\text { Részesedés, \% } \\
\text { (Share, \%) }\end{array}$ & $\begin{array}{c}\text { Népesség, fó } \\
\text { (Population, Capita) }\end{array}$ \\
\hline Muszlim (Muslim) & 23,20 & 1666157904 \\
\hline Hindu (Hindu) & 15,00 & 1077257266 \\
\hline Buddhista (Buddhism) & 7,10 & 509901772 \\
\hline Izraelita (Jewish) & 0,20 & 14363430 \\
\hline Összesen (Total) & 45,50 & 3267680372 \\
\hline
\end{tabular}

Forrás (Source): A CIA adatai alapján saját számítás, 2016 (Own calculation according to CIA’s data, 2016)

\subsection{A társadalmi-demográfiai környezet hatása a világ sertéshús- fogyasztására - Socio-demographic Environmental Impact on the Global Pork Consumption}

A globális gazdasági terjeszkedés és a népesség folytatódó, noha lassuló ütemű (éves átlagban 1,1\% körüli) növekedése nyomán várhatóan tovább élénkül az élelmiszerek iránti kereslet. Ha hihetünk az előrejelzéseknek, tíz év múlva a világ lakosságának 84\%-a a fejlődő és feltörekvő országokban, egyharmada Kínában és Indiában él majd. Az élelmiszerkereslet növekedésében a fogyasztói szokások változása is szerepet játszik. Kínában már a népesség 20\%-a, mintegy 300 millió fó engedheti meg magának a magasabb színvonalú étkezést. Indiában kialakult egy 150-200 milliós, jómódú, évi mintegy 30 millió fővel bővülő középosztály, amelynek élelmiszerfogyasztási struktúrája mind inkább a nyugat-európaihoz hasonlítható. A táplálkozási szokások gyors változása többek között a globális urbanizációval is összefügg. A földmüveléssel felhagyó emberek tömegei költöznek a városokba, ahol - részben az életszínvonal növekedésének köszönhetően - étkezési szokásaik megváltoznak. Strukturális természetű folyamatról van szó, amely összességében növeli a keresletet (POPP és POTORI, 2009).

Az egyre nagyobb méreteket öltő fogyasztói társadalom a következő évtizedben az egy före jutó éves átlagos húsfogyasztás 6,1 kg-os növekedését vonja maga után, ami éves szinten 1,3\%-os növekedést jelent. Az összes húsfogyasztásunk eléri az 54,5 kg/fő/év értéket 2019-re. A fogyasztói kosárból való részesedést tekintve a sertéshúsfogyasztásnak van a legnagyobb aránya, amely globális szinten a három fő húsféle közül (sertés, baromfi, marha) még mindig a legdinamikusabban növekszik (FAPRI, 2010).

A fejlődő világban a gyorsan növekvő jövedelmek a feldolgozott termékek, és állati eredetű termékek irányába tolja el a fogyasztást. Emellett ROSEGRANT et al., 2001-ben készült tanulmánya kimutatta, hogy az urbanizálódott lakosságnak magasabb az élelmiszerfogyasztása, és a magasabb élelmiszerfogyasztás (főként a gabonanövények, a húsfélék) egyre nagyobb 
terhet ró a környezetre is.

A FAOSTAT adatbázisa alapján a legfrissebb statisztikák azt mutatják, hogy a világ népességének 53,8\%-a városokban lakik, és ez az arány csak növekedni fog a jövőben. Az urbanizálódott lakosság fogyasztásán belül kiemelkedően magas arányú a feldolgozott termék, és relatíve alacsony arányú az alapvető élelmiszerfogyasztás.

Egy másik tanulmányban arra is rámutattak, hogy ha ez a trend továbbra is így folytatódik, 2020-ra elérhetjük, hogy a feldolgozatlan nyers hús és a nyers tejfogyasztás 60\%-át a fejlődő országok adják, és ezeknek a termékeknek az összes termelése pedig legalább duplája lesz az 1993-as szintnek (DELGADO et al., 1999).

A világ szinten lezajló urbanizációs folyamatokkal egyre távolabb kerülnek egymástól a termelés és fogyasztás földrajzi helyszínei is. A globalizáció mellett megjelent egy olyan fogyasztói trend, amely hatására nő a változatosság, az eredeti, hamisítatlan ízü, hagyományos élelmiszerek, húsféleségek iránti igény. Az életszínvonal várható javulásával a magasabb hozzáadott értékü, kényelmi funkciókat, táplálkozástani, érzékszervi előnyöket nyújtó élelmiszerek iránti igény fokozódik és várhatóan egyre nagyobb teret nyernek az egyedi fogyasztói igényeknek megfelelően „egyénre szabott” élelmiszerek (ÉFOSZ, 2009).

$\mathrm{Az}$ élelmiszerfogyasztás Kínában és Latin-Amerikában is növekvő tendenciát mutat a jövedelmek stabilizálódása miatt, ám Afrikában - a Szaharától délre - a jövedelmek egyenlőtlen elosztása miatt nem várható számottevő növekedés. Hosszú távon az aggregált egy főre jutó fogyasztás az előrejelzések szerint Kelet-Európában és Közép-Ázsiában is dinamikusan fog bővülni, mivel a jövedelmek növekedése mellett a népesség számának stagnálása vagy csökkenése várható (OECD-FAO, 2011).

A legfrissebb FAO, 2016 adatok szerint a világ hústermelése 319,609 millió tonna volt 2015-ben, melynek jelentős része - 117,239 millió tonna - sertéshúsból származott, mely a teljes hústermelés több mint 36\%-át tette ki. A világ sertéshústermelésének felét, 56,6\%-át Ázsia adja $(66,42$ millió tonna hasított súlyban mérve), ezen belül is a világ legnagyobb sertéshústermelője Kína (55,392 millió tonna). Kína sertéshústermelése egyedül nagyobb mértékű, mint Európa, Észak- és Dél-Amerika sertéshústermelése együttesen. Ebből azt a következtetést vonhatjuk le, hogy Kína sertéshús termelésének tendenciája jelentősen kihat a világ sertéshús termelésének tendenciájára, sőt, egyedül képes befolyásolni a világ sertéshús termelésének alakulását.

A globális húskereskedelmet tekintve az import és az export közel azonos mértékű volt 2015-ben. Míg az import mértéke 29,21 millió tonna hús volt hasított súlyban, az export 29,79 millió tonna volt. A sertéshús esetében is hasonlóan alakult a helyzet, míg az import 7,19 millió tonna volt, az export is 7,2 millió tonna sertéshús volt, gyakorlatilag azt mondhatjuk, hogy egyensúlyban volt. A legnagyobb sertéshús exportőrök között az Európai Uniót említhetjük (2,4 millió tonna), majd az Egyesült Államok (2,1 millió tonna), és Kanada (1,2 millió tonna) a legmeghatározóbb. A legnagyobb importőr országok sertéshúsból Kína (1,5 millió tonna), Japán (1,2 millió tonna), Mexikó (o,8 millió tonna), az USA (o,6 millió tonna) és Oroszország (0,4 millió tonna) (FAO, 2016).

A 2016-os előrejelzések szerint a világ öszszes hústermelése 320,688 millió tonnára növekszik, és ezen belül a sertéshús termelése (116,4 millió tonna) továbbra is a legjelentősebb részarányt fogja képviselni, de a baromfihús termelés (116,2 millió tonna) megközelíti a sertéshús előállítását, és az előrejelzések szerint az elkövetkező években akár meg is haladja azt (FAO, 2016).

Ha a sertéshús iránti növekvő keresletet, az urbanizációt és a népességnövekedést említjük, akkor mindenkinek Kína jut az eszébe a világra, az élelmiszertermelésre és fogyasztásra, valamint a kereskedelemre gyakorolt hatása miatt. Azért mutatjuk be részletesen Kína sertéshús fogyasztását, mert jelenleg és a jövőben is ők lesznek a legmeghatározóbbak a sertéshús piacán, mint fogyasztó, mint termelő, és mint importőr is. A sertéshús iránt Kínában mutatkozik a leginkább növekvő igény, az urbanizációs folyamatok és a népesség növekedése szintén hozzájárulnak ehhez. Kína egy főre jutó sertéshúsfogyasztása az elmúlt évtizedekben jelentősen megnövekedett, mindez látható az 1. ábrán is. 


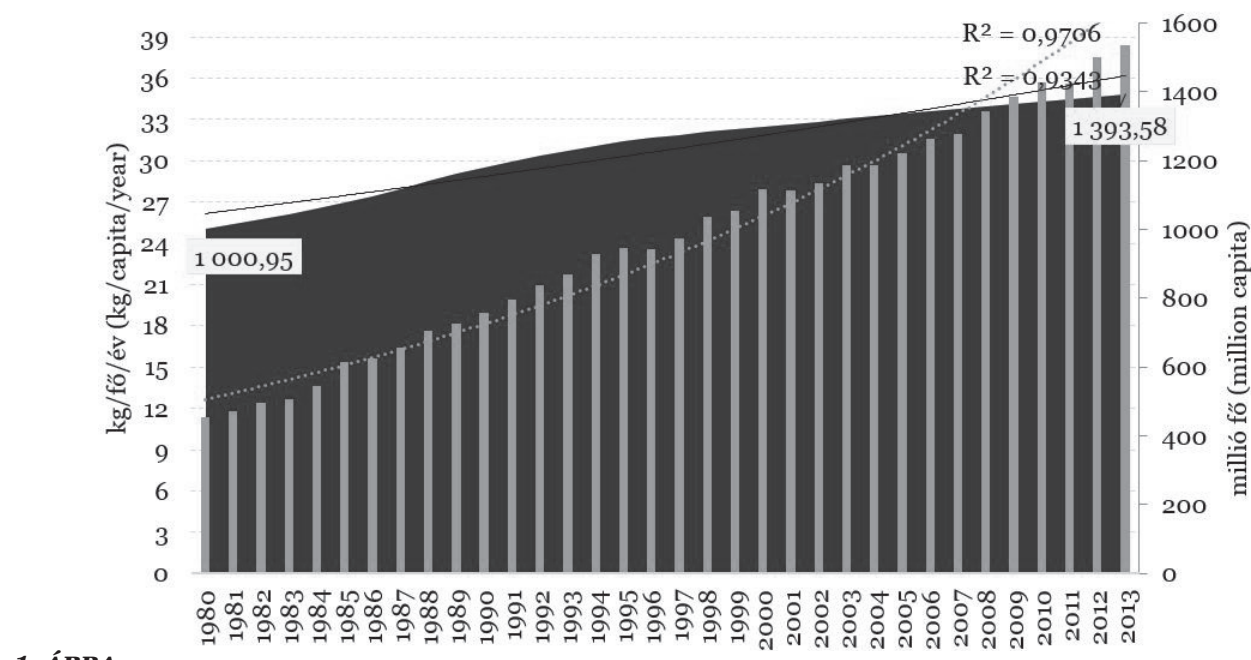

1. ÁBRA

Kína egy fóre jutó sertéshúsfogyasztása és népességé 1980-2015 (The Pork Consumption and Population of China 1980-2015)

FIG. 1

Forrás (Source): A FAOSTAT adatai alapján saját készítés, 2016 (Own construction according to FAOSTAT’s data, 2016)

Az 1. ábráról leolvasható, hogy Kína népessége 1980-ban lépte át az 1 milliárd fót, és azóta 2013-ra elérte a 1,3935 milliárd föt, és - bár az ábrán nem szerepel, de a legfrissebb FAOSTAT adatok szerint - 2014-ben lépte át az 1,4 milliárdot. A sertéshúsfogyasztása az 1980-as évek szintjéhez képest $(11,39$ $\mathrm{kg}$ /fö/év) 2013-ra elérte a 38,5 kg/fö/év értéket. Ez az érték megháromszorozódott, de ha az 1961-es értékhez viszonyítjuk, amely a legkorábbi pontos adat a FAOSTAT adatbázisában (2,36 kg/fő/év), akkor napjainkra gyakorlatilag meghúszszorozódott Kína egy főre jutó sertéshúsfogyasztása. Ennek magyarázata, hogy Kínában az 1950-es és 60-as évek éhínsége után, az 1970-es évek vége felé a kormány a mezőgazdaság liberalizációját hajtotta végre. Így a kínai gazdaság fellendülése és a sertéshús fogyasztása és termelése között párhuzamot lehet felfedezni, ami több, mint szimbolikus jelentésű. Kína sertés(hús) iránti vágya komoly következményekkel jár az ország gazdaságára és környezetére, így a világ számára is. A sertéstartás és a sertéshúsfogyasztás több ezer éve a kínai kultúra, a konyhamúvészet és a családi élet középpontjában áll. Mandarin nyelven a „hús” szót és a „sertés” szót ugyanúgy írják. A 12 kínai állatöv egyik eleme a disznó, akik ennek évében születtek, azokra azt mondják, hogy szorgalmas, szimpatikus és nagylelkű emberek. A kínai kultúrában a sertés jelenti a jólétet, a termékenységet és a férfiasságot, versekkel, történetekkel és dalokkal ünnepelik őket. Évszázadokon keresztül áldozati állat volt a sertés, és a sertéshúsevés kiemelt szerepet kapott az összes megemlékezésen és ünnepen. A „kommunista” korszakban szinte minden vidéki háznál megtalálható volt egy sertés, nem utolsósorban azért, mert az állatok részét képezték a háztartások újrahasznosító rendszerének. Elfogyasztották az egyébként ehetetlen hulladékot és trágyát állítottak elő (Mao Ce-tung szerint a sertés „mütrágya gyár négy lábon”). A sertéshús fogyasztásában eltérnek az európai kultúrától, mivel gyakorlatilag minden részét elfogyasztják, semmi sem vész kárba. A sertés fejét egészben szolgálják fel, mint egy ínyenc csemegét, az agyuk, „puha, mint a puding, és tápanyagban gazdag”, a belsőségeknek terápiás előnyöket tulajdonítanak. A nyolcvanas években a kínai sertés 95\%-a olyan háztáji gazdaságokból származott, ahol kevesebb, mint öt sertést tartottak. Mára ez az arány már csak 20\%. Összességében elmondható, hogy a kínai történelemben a disznók a luxus, a gazdagság szimbólumai voltak, és csak ritkán fogyasztották, de ez mára drámaian megváltozott (LUXI COUNTY, 2014). Megjegyezzük, hogy 
a szegényebb ázsiai országokban, a kövérség, mind a mai napig a gazdagság egyik külső megnyilvánulása, ami közvetlen asszociációt mutat a sertéssel, illetve a sertéshúsfogyasztással.

Ha Kína étvágya a sertéshús iránt továbbra is így folytatódik, komoly kihívás elé nézünk a 21. század végére. A kínai lakosság körében figyelhető meg a legdinamikusabban az urbanizációs folyamatok növekedése is (az elmúlt 15 évben az urbanizálódott lakosság aránya 67\%-os növekedést ért el), ma már a FAOSTAT 2015-ös adata alapján mintegy 805,4 millió kínai ember él városokban.

A népesség növekedése szempontjából a 2010-2015 közötti időszakban nem Kína rendelkezik a legdinamikusabban növekvő népességgel, hanem India. Ezt támasztja alá a termékenységi mutató (egy nőre jutó gyermekek száma) vizsgálata is, hiszen Kína ez időszakban a második helyen van 1,2-es értékkel. Csak érdekesség, hogy a világ átlag termékenységi mutatója 2,51, és a növekvő sorrendben lévő lista 10. helyén Magyarország található 1,34-es értékkel (ESA, 2015).

Ezek a fentebb említett adatok a sertéshús szempontjából azt a problémát vetik fel, hogy a világon a megtermelt sertéshús tudja-e követni ezt a fokozódó fogyasztói igényt, ami iránta mutatkozik azokban az országokban, ahol a sertéshús fogyasztása nem esik vallási korlátozás alá.

A világon a megtermelt sertéshúst majdnem el is fogyasztjuk, nagyjából egyenlőség van a két adat között. A világ sertéshús termelésének és fogyasztásának felét Kína adja. Az előrejelzések szerint 2015-ben a világon a megtermelt összes sertéshús mennyisége várhatóan 117239 millió tonna, 2016-ban pedig 116402 millió tonna, a felhasználás pedig 117417 millió tonna 2015-ben, és 116488 millió tonna 2016ban. Ebből látható, hogy a fogyasztás meghaladja az elő́llított mennyiséget, amely azért is történhet meg, mert Kínában állategészségügyi problémák miatt több millió egyed kiesett a termelésből. A termelés és a fogyasztás közötti különbséget még egy ideig a fagyasztott sertéshús készletekból fedezik. Ha ez a mennyiség viszont egyre jelentősebbé válik, válságba kerülhet a sertéshús fogyasztása. A sertéshúsfogyasztás nem azért fog csökkenni, mert nincs iránta kereslet, hanem mert nem lesz elegendő a lakosság számára.

A jövőbe tekintve vannak olyan kezdeményezések, pozitív változások, amelyek a fentebb említett növekvő fogyasztási folyamatokat korlátoznák. A kínai kormány jelentős kormányzati intézkedéseket kíván bevezetni a sertéshús iránti fogyasztás mérséklésére, és ezzel a szabályozással az üvegházhatású gázok kibocsátását is szeretné redukálni. Terveik szerint ezzel a korlátozással 2030-ra évi 1 milliárd tonnával csökkenthetnék az üvegházhatású gázok kibocsátásának mértékét, mert a káros gázok kibocsátásának 14,5\%-ért a haszonállattartás felelős, ami meghaladja többek között a teljes szállítási szolgáltatói szektorét. A kérődző állatok által emésztése által felszabaduló metán, valamint a trágyázás és a természetes vegetációk/esőerdők irtásának a globális szén-dioxid-háztartásban van jelentős szerepe.

Kína egészségügyi minisztériuma azt tanácsolja az ország 1,4 milliárd lakosának, hogy személyenként átlagosan napi 40 és 75 gramm közötti mennyiségben fogyasszanak sertéshúst. Egyes - bár sokak által vitatott - felmérések szerint az elhalálozások közel 85 százalékban kapcsolatban állnak a túlzott húsfogyasztással (ezen belül is a sertéshús fogyasztásával), így elsősorban egészségügyi megfontolásokból javasolják a változást. A Kínai Kommunista Párt már talált az intézkedéshez hollywoodi szövetségeseket is, Arnold Schwarzenegger és James Cameron segítségével készítenek egy reklámfilmeket, amivel az új szabályozást népszerüsítenék. Az előzetes felmérések szerint a kínai fogyasztók nyitottak a változásra az egészségük és a környezet pozitív változása érdekében (PÁNDI, 2016). 


\section{KöVETKEZTETÉSEK ÉS}

\section{JAVASLATOK - CONCLUSIONS AND} SugGESTIONS

A világ élelmezésében a sertéshús évezredek óta jelentős szerepet játszik, amelynek következtében a sertéstartás világszerte kiemelkedő fontosságú állattenyésztési ágazatnak számít. Az előrejelzések szerint a megtermelt sertéshús mennyisége az elkövetkezendő években is növekvő tendenciát fog mutatni, melynek köszönhetően 2023-ra megközelíti a 130 millió tonnás mennyiséget. Ennek a mennyiségnek a legnagyobb részét Kína fogja adni, mert a lakosság körében a sertéshús a legnépszerúbb húsféleség. Ez a „népszerűség” növekvő fogyasztást, az pedig növekvő keresletet generál, ami pedig növeli a sertéshús előállítását is. Kína esetében a sertéshús fogyasztását nem korlátozza a kultúra és a vallási hovatartozás.

A muszlim, izraelita, buddhista, hindu vallást gyakorlók a vallási korlátozások miatt nem fogyasztanak egyáltalán sertéshúst, ami azt jelenti, hogy a világ sertéshús fogyasztásából a részesedésük gyakorlatilag nulla. Ezt alapul véve számoltuk át a világ átlagos egy főre jutó sertéshús fogyasztását bemutató értéket (kg/fó/év). A korrekciós számítás során a világ népességét csökkentettük a fentebb említett vallási felekezethez tartozók létszámával, majd ezzel az értékkel osztottuk el a világon elfogyasztott sertéshús mennyiségét. A kalkuláció elvégzése után a kapott eredményt elemezve megállapítható, hogy ez az adat a hivatalos statisztikai adat majdnem duplája. Ebből azt a következtetést vonhatjuk le, hogy világ népességének majdnem fele nem fogyaszt sertéshúst, így a népesség fennmaradó része pedig $30 \mathrm{~kg} /$ fő/év körüli mennyiséget fogyaszt el sertéshúsból. Ez az érték várhatóan a jövőben növekedni fog, mert szúkül a világon a sertéshús fogyasztók aránya (a vegetáriánus táplálkozás is egyre inkább terjedóben van), ami pedig az egy főre eső mennyiségi fogyasztást növeli.
Összességében megállapítható, hogy a globális hústermelés továbbra is pozitív irányba fog elmozdulni, a legnagyobb sertéshústermelő pedig - mint már sok éven át - Kína lesz. A hústermelésben vezető helyet hosszabb távon a baromfihús fogja elfoglalni, ezt követi majd (nem sokkal lemaradva) a sertéshús, amelynek mennyisége kisebb mértékben fog emelkedni, mint a baromfié.

\section{5. ÖSSZEFOGLALÁS - SUMMARY}

A fentebb leírtak alapján zárásként megállapíthatjuk, hogy - a jelenlegi legnagyobb sertéshúsfogyasztó Kínában - a globalizációs és urbanizációs folyamatok hatására a sertéshúsfogyasztás további növekedésére számíthatunk, hiszen a falvakból városokba áramló népesség fogyasztói szokásai a városi fogyasztás irányába változnak. Kínában a sertéshúsfogyasztás igen magas, a lakosság legkedveltebb és legtöbbet fogyasztott húsfélesége, a fogyasztás értéke a FAOSTAT adatbázisa alapján 2013-ra elérte a $38,5 \mathrm{~kg} /$ fö/év értéket, és a Kínához tartozó Hong Kongban az egy före jutó sertéshúsfogyasztás a 65,7 kg-ot éri el (USDA, 2011). Ez jól reprezentálja azt, hogy az urbanizálódott, városiasodott lakosság fogyasztása a mennyiségi fogyasztás felé tolódik, ami a fő húsféleség, a sertéshús növekvő fogyasztását vetíti előre, igaz a kormányzati intézkedések lassíthatják a növekedés dinamikáját.

A jövőre nézve ez azt jelenti, hogy a növekvő népesség egy részének, a kínai lakosság oldaláról számíthatunk a sertéshús világpiaci fogyasztásának növekedésére, amely egyre nagyobb nyomást gyakorol a klímaváltozáson, a zsugorodó termőterületeken, és a trágyakezelésen keresztül a környezetre is.

Végezetül elmondható, hogy a sertéshús és húsfogyasztás vizsgálata során egyre inkább figyelembe kell venni a kulturális és vallási kérdéseket, amelyek nagymértékben meghatározzák a népesség fogyasztói mutatóit, és az elfogyasztható élelmiszerek körét. 
IRODALOMJEGYZÉK - REFERENCES

Delgado, C. L. - Rosegrant, M. W. Steinfeld, H. - Ehui, S. - Courbois, C.: Livestock to 2020 - The Next Food Revolution. International Food Policy Research Institute, Washington, D.C., 1999.

Eihit: A sertéshús fogyasztásának egészségkárosító hatásai. 2011. URL: http://eihit.com/?url=320 (Letöltés dátuma: 2011. szept. 10.)

ÉFOSZ: Élelmiszer feldolgozók Országos Szövetsége: Társadalmi változások, fogyasztói igények, jogszabályok. In: Magyar Nemzeti Élelmiszer-technológiai Platform „Élelmiszer Az Életért” Program, A magyar élelmiszeripar egyeztetett innovációs stratégiája (2009-2024). 2009. május. 10. 18-21.

ESA: World Population Prospects. 2015. URL: https://esa.un.org/unpd/wpp/ publications/files/key_findings_ wpp_2015.pdf (Letöltés dátuma: 2016. szept. 26.)

FAPRI: U.S. And World Agricultural Outlook. Published by Food and Agricultural Policy Research Institute, USA, 2010.

FAO: Food Outlook. Biannual Report On Global Food Markets. Published by Food and Agricultural Organization of the United Nations, 2016.

Krisna: A lelki étel. 2011. URL: http://krisna. hu/tanitasaink/a-lelki-etel/ (Letöltés dátuma: 2011. nov. 11.)

Lehota J.: Élelmiszer-gazdasági marketing. Müszaki Könyvkiadó, Budapest, 2001.

Luxi County, J.: Swine in China - Empire of the pig. The Economist. 2014. december 20. URL: http://www.economist.com/ news/christmas-specials/21636507chinas-insatiable-appetite-pork-symbolcountrys-rise-it-also (Letöltés dátuma: 2016. szept. 21.)

Morvay S. Á.: A vegánok mentik meg a Földet? Hetek, Országos Közéleti Hetilap. 2016. 20 (14) 18-22.
OECD-FAO: $\quad O E C D-F A O \quad$ Agricultural Outlook 2011-2020. Published by OECD Publishing and FAO, 2011.

Pándi B.: Kína a felére csökkentené a húsfogyasztását 2030-ra. 2016. URL: http://index.hu/tudomany/2016/o6/21/ kina_felere_csokkentene_a_hus fogyasztasat_2030-ra/ (Letöltés dátuma: 2016. szept. 21.)

Popp J. - Potori N.: Az élelmezés-, energia- és környezetbiztonság összefüggéseiról. Párbeszéd és összefogás a Közös Agrárpolitika megújításáért. A II. Magyar Agrárakadémia gondolatai, vitái és dokumentumai. 2009.

Rosegrant, M. W. - Paisner, M. S. Meijer, S. - Witcover, J.: Global Food Projections to 2020 - Emerging Trends and Alternative Futures. International Food Policy Research Institute, Washington, D.C., 2001.

The Poultry Site: Global Consumption, Production and Trade Patterns. 2009. URL: http://www.thepoultrysite. com/poultrynews $/ 16876 / \mathrm{cme}$-globalconsumption-production-and-tradepatterns (Letöltés dátuma: 2010. nov. 22.)

The World Factbook: URL: https://www. cia.gov/library/publications/the-worldfactbook/geos/ch.html, 2016. (Letöltés dátuma: 2016. szept. 20.)

Tusor A.: Vallási étkezési előírások. 2011. URL: http://mek.niif.hu/o010o/o0129/ html/4fejezet.htm (Letöltés dátuma: 2011. aug. 26.)

USDA: United States Department of Agriculture: Oil Crops Yearbook 2011. Published by United States Department of Agriculture - Foreign Agricultural Service. USA, 2011.

Yadav, Y. - Kumar, S.: The Food Habits of a Nation. 2006. URL: http://www.thehindu. com/todays-paper/article3089973.ece (Letöltés dátuma: 2011. okt. 11.) 


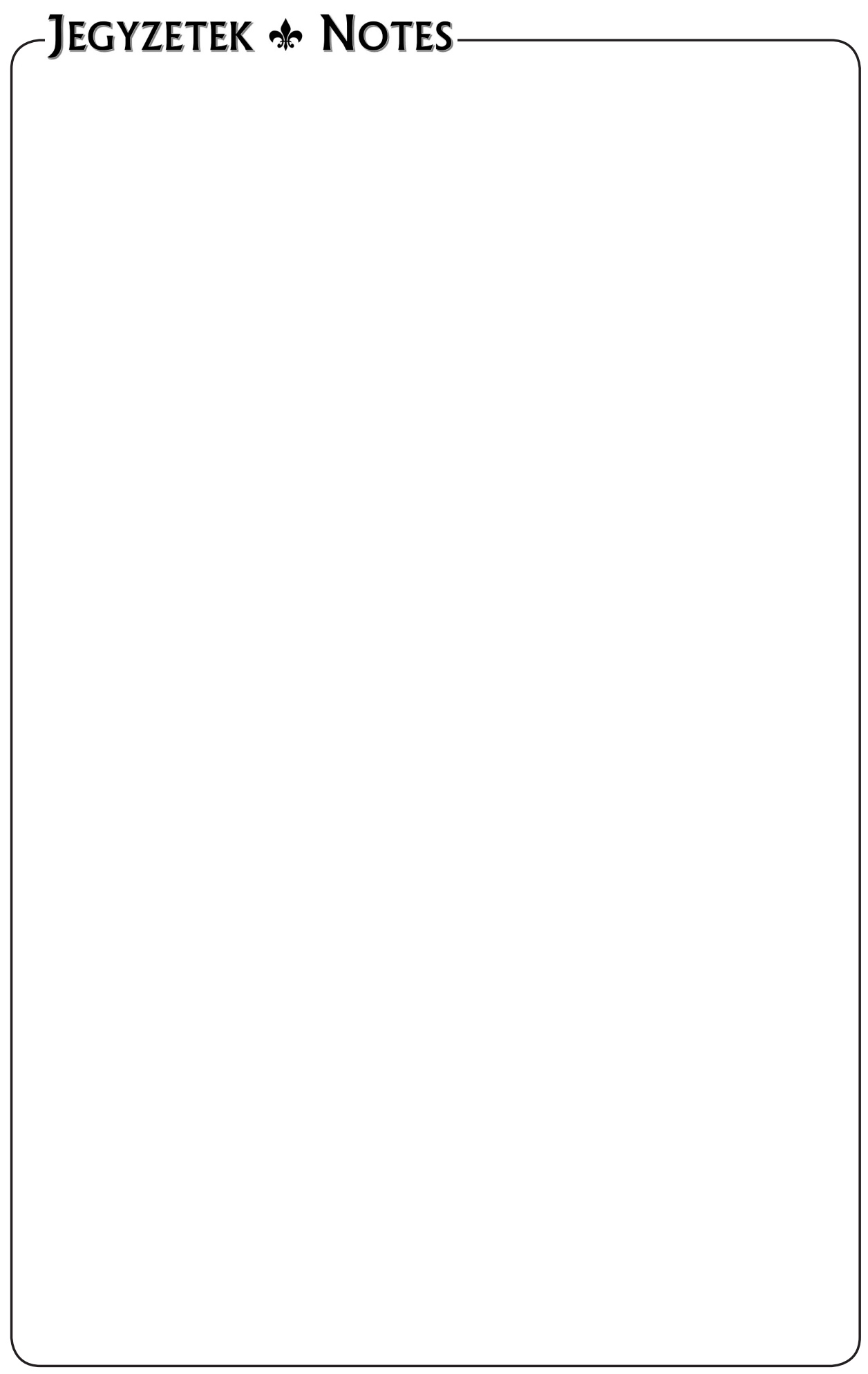

